\title{
An appeal to humanity: legal victory in favour of North America's only supervised injection facility: Insite
}

Dan Small ${ }^{1,2}$

\begin{abstract}
Canada's federal government has once again failed to shut North America's only authorized supervised injection facility: Insite. A majority ruling issued by the BC Court of Appeal on 15 January 2010 upheld an earlier British Columbia Supreme Court ruling in 2008 that protected the rights of injection drug users (IDUs) to access Insite as a health facility as per the Charter of Rights and Freedoms component of the Constitution of Canada. The majority decision from Honourable Madam Justices Rowles, Huddart and Smith also established a jurisdictional victory safeguarding Insite as most appropriately run under the authority of the province of British Columbia rather than the federal Government of Canada. The Federal Government has appealed the case to the Supreme Court of Canada. A hearing date has been set for 12 May 2011. The appeal will be a legal one but even more so, it will be an appeal to humanity.
\end{abstract}

Canada's federal government has once again failed to shut North America's only authorized supervised injection facility: Insite. A majority ruling issued by the $\mathrm{BC}$ Court of Appeal on 15 January 2010 upheld an earlier British Columbia Supreme Court ruling in 2008 that protected the rights of injection drug users (IDUs) to access Insite as a health facility as per the Charter of Rights and Freedoms component of the Constitution of Canada.

The majority decision from Honourable Madam Justices Rowles, Huddart and Smith also established an important jurisdictional victory emerging from the cross appeal by the operators of Insite: the PHS Community Services Society (PHS). The ruling further safeguards Insite as most appropriately run under the authority of province of British Columbia rather than the federal Government of Canada.

Insite opened on 21 September of 2003 under an exemption granting it status as a scientific pilot study until 12 September 2006. The primary goals of the program are: (1) to reach a marginalized group of IDUs with healthcare and supports who would otherwise be forced

Correspondence: dansmall@interchange.ubc.ca

1 Director PHS Community Services Society Vancouver, Canada

Full list of author information is available at the end of the article to use drugs in less safe settings (2) to reduce dangerous injection practices (syringe sharing) thereby reducing the risk of infectious diseases like HIV and HCV; and (3) to reduce fatal overdoses in the population of people that use the facility. The program also aims to provide referrals to treatment and detoxification, reduce public disorder (public injection) and validate the personhood of a deeply stigmatized target population [1].

The legal battle began near the end of Insite's threeyear exemption for scientific study when a minority conservative government was elected in Canada on 6 February 2006. The new government voiced opposition to the program during and after the election [2-4]. On 1 September 2006, the program was given a temporary extension to operate until 31 December of 2007. Before this reprieve, the community waited in apprehension. The photograph below (Figure 1) shows an announcement of support for the supervised injection facility from a humble church in the inner city of Vancouver where Insite makes its home. This same church opens its pews up each night for the homeless to sleep and has held many services for local residents who died of preventable overdoses before Insite was opened. [insert figure here] For the people living with addictions and their families who face the dangers of preventable overdoses and infections in their everyday lives, the fate of 


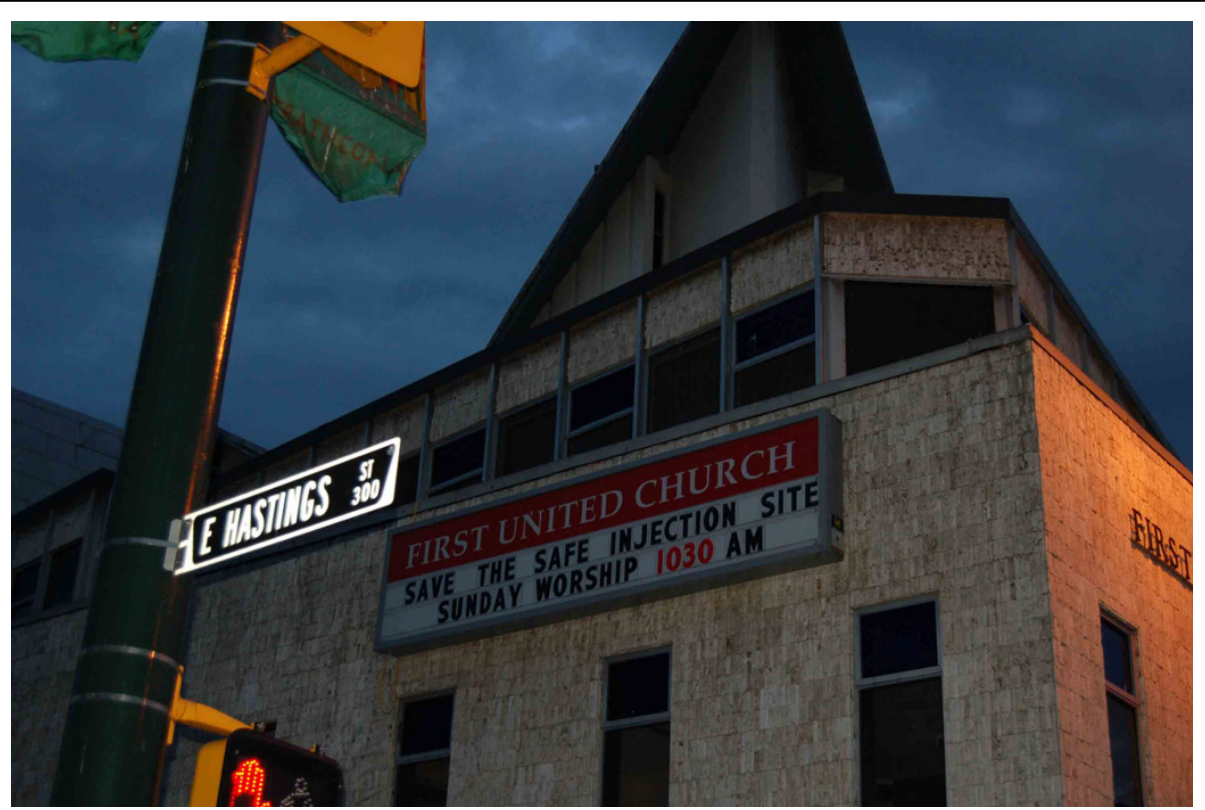

Figure 1 Photograph of church marquee advertising an upcoming sermon in Vancouver's downtown eastside. Photograph by D. Small

the injection facility is neither academic nor legal. It is risk that is lived [5].

On 2 October 2007, the project was given an additional exemption to operate under the Controlled Drugs and Substances Act until 30 June 30 2008. A looming threat of closure by the conservative led government led the PHS to take the Government of Canada to court in late 2007 [6]. The outcome of this first legal case determined that the Controlled Drugs and Substances Act (CDSA) in Canada is unconstitutional as it pertains to Insite because the closure of the program under the Act would impede people with addictions from receiving life saving healthcare. BC Supreme Court Justice Ian Pitfield ruled that the use of the CDSA to shut Insite would undermine the fundamental right, under Canada's Charter of Rights and Freedoms to life, liberty and security of the person [7].

Since its inception, Insite has been subject to an independent review by a team of physicians and scientists put in place to provide an "arm's length" evaluation of the program. The results of this scientific evaluation have been published in peer-reviewed academic journals and have indicated that Insite has reduced unsafe injection practices, public disorder, overdose deaths and $\mathrm{HIV} / \mathrm{Hepatitis}$ while increasing uptake of addiction services and detox [8]. To date, there have been over three-dozen peer-reviewed papers evaluating Insite published making it one of the most evaluated healthcare programs in the history of Canada [9-38]. In light of the evidence, the program has garnered widespread support from Canadian physicians, scientists and healthcare professionals [39].
Despite this support from the scientific and medical community, the Conservative government of Canada remains entrenched in its position having served the PHS with court documents indicating their intention to appeal the case of Insite to the highest court in the country: the Supreme Court of Canada [40]. A court date to hear the case has been set for 12 May 2011 by the Supreme Court of Canada. It appears that science and ideology are once again at odds while Canada's highest court is asked to determine whether the earth is flat or round in the universe of addiction. When Insite reaches the end of its legal journey in Canada, hopefully the courts will once again rule that addiction is principally an issue for the Chief of Medicine rather than the Chief of Police. As a result, the case is more than an appeal to the Canada's highest court; it is an appeal to the country's humanity.

\section{Author details}

${ }^{1}$ Director PHS Community Services Society Vancouver, Canada. ${ }^{2}$ Department of Anthropology University of British Columbia Vancouver, Canada.

\section{Competing interests}

The author declares that they have no competing interests.

Received: 6 July 2010 Accepted: 9 October 2010

Published: 9 October 2010

\section{References}

1. Small D: Looking in the cultural mirror: addiction, secret lives and lost personhood. Visions Journal 2005, 2:29-30.

2. Small D: Fools rush in where angels fear to tread: Playing God with Vancouver's supervised injection facility. International Journal of Drug Policy 2007, 18:18-26. 
3. Canada: Standing Committee on Health: Transcript of Meeting Thursday, May 29, 2008.Edited by: Health SCo. Ottawa: Government of Canada; 2008:

4. Galloway G: Clement seeks appeal of Insite decision. Globe and Mail Toronto: CTV globe media 2008.

5. Gifford SM: The Meaning of Lumps: A Case Study of the Ambiguities of Risk. In Anthropology and Epidemiology. Edited by: Janes CR. D. Reidel Publishing Company; 1986:213-246.

6. Small D: Fighting addiction's death row: British Columbia Supreme Court Justice lan Pitfield shows a measure of legal courage. Harm Reduction Journal 2008, 5:1-18.

7. Pitfield THMJ: PHS Community Services Society v. Attorney General of Canada, 2008 BCSC 661. The Supreme Court of British Columbia 2008.

8. Small D: Amazing grace: Vancouver's supervised injection facility granted six-month lease on life. Harm Reduction Journal 2008, 5:1-6.

9. DeBeck K, Wood E, Zhang R, Tyndall M, Montaner J, Kerr T: Police and public health partnerships: Evidence from the evaluation of Vancouver's supervised injection facility. Substance Abuse Treatent, Prevention and Policy 2008, 3:1-5.

10. Fairburn N, Small W, Shannon K, Wood E, Kerr T: Women's Experiences in North America's First Medically Supervised Safer Injection Facility. Social Science and Medicine Forthcoming

11. Kerr T, Kimber J, DeBeck K, Wood E: The Role of Safer Injection Facilities in the Response to HIV/AIDS Among Injection Drug Users. Current HIV/ AIDS Reports 2007, 4:158-164.

12. Kerr T, Small W, Moore D, Wood E: A Micro-Environmental Intervention to Reduce Harms Associated with Drug-Related Overdose: Evidence from the Evaluation of Vancouver's Safer Injection Facility. International Journal of Drug Policy 2007, 18:37-45

13. Kerr T, Stoltz J, Tyndall M, Li K, Zhang R, Montaner J, Wood E: Impact of a Medically Supervised Safer Injection Facility on Community Drug Use Patterns: A Before and After Study. British Medical Journal 2006, 332:220-222.

14. Kerr T, Tyndall MW, Lai C, Montaner JSG, Wood E: Drug-Related Overdoses Within A Medically Supervised Safer Injection Facility. International Journal of Drug Policy 2006, 17:436-441.

15. Kerr T, Tyndall MW, Lai C, Montaner JSG, Wood E: Circumstances of First Injection Among Illicit Drug Users Accessing a Medically Supervised Safer Injecting Facility. American Journal of Public Health 2007, 97:1228-1220.

16. Kerr T, Tyndall MW, Li K, Montaner JS, Wood E: Safer Injecting Facility Use and Syringe Sharing Among Injection Drug Users. Lancet 2005, 366:316-318

17. Kerr T, Wood E, Small D, Palepu A, Tyndall MW: Potential Use of Safer Injecting Facilities Among Injection Drug Users in Vancouver's Downtown Eastside. Canadian Medical Association Journal 2003, 169:1-5.

18. McKnight I, Maas B, Wood E, Tyndall MW, Small W, Lai C, Montaner JSG, Kerr T: Factors Associated with Public Injecting Among Users of Vancouver's Supervised Injection Facility. American Journal of Drug and Alcohol Abuse 2007, 33:319-325.

19. Milloy MJ, Wood E, Small W, Tyndall M, Lai C, Montaner J, Kerr T: Incarceration experiences in a cohort of active injection drug users. Drug and Alcohol Review 2008, 1-7.

20. Petrar S, Kerr T, Tyndall MW, Zhang R, McKnight B, Montaner JSG, Wood E: Injection Drug Users' Perceptions Regarding Use of a Medically Supervised Safer Injecting Facility. Addictive Behaviors 2007, 32:1088-1093.

21. Stoltz JA, Wood E, Small W, Li K, Tyndall M, Montaner J, Kerr T: Changes in injecting practices associated with the use of a medically supervised injection facility. Journal of Public Health (Oxford) 2007, 29:35-39.

22. Tyndall MW, Kerr T, Zhang R, King E, Montaner JG, Wood E: Attendance, Drug Use Patterns, and Referrals Made From North America's First Supervised Injection Facility. Drug and Alcohol Dependence 2005, 83:193-198.

23. Tyndall MW, Wood E, Zhang R, Lai C, Montaner JS, Kerr T: HIV Seroprevalence Among Participants at a Supervised Injection Facility in Vancouver, Canada: Implications for Prevention, Care and Treatment. Harm Reduction Journal 2006, 3:1-5.

24. Wood E, Kerr T, Buchner C, Marsh D, Montaner JS, Tyndall MW: Methodology for Evaluating Insite: Canada's First Medically Supervised Safer Injection Facility for Injection Drug Users. Harm Reduction Journal 2004, 1:1-5.
25. Wood E, Kerr T, Montaner JS, Strathdee S, Kerr T, Wodak A, Spittal P, Hankins C, Schechter MT, Tyndall M: Rationale For Evaluating North America's First Medically Supervised Injecting Facility. Lancet Infectious Diseases 2004, 4:301-306.

26. Wood E, Kerr T, Small W, Li K, Marsh D, Montaner JS, Tyndall MW: Changes In Public Order After The Opening of a Medically Supervised Safer Injection Facility for Injection Drug Users. Canadian Medical Association Journal 2004, 171:731-734.

27. Wood E, Kerr T, Stoltz J, Qui Z, Zhang R, Montaner JSG, Tyndall MW: Prevalence and correlates of hepatitis C among users of North America's first medically supervised safer injection facility. Public Health 2005, 119:1111-1115

28. Wood E, Kerr T, Tyndall MW, Montaner JSG: The Canadian government's treatment of scientific process and evidence: Inside the evaluation of North America's first supervised injecting facility. The International Journal of Drug Policy 2007, 1-6.

29. Wood E, Montaner JS, Kerr T: Reflection and Reaction: Illicit drug addiction, infection disease spread, and the need for an evidence-based response. Lancet 2008, 8:142-143.

30. Wood E, Tyndall MW, Lai C, Montaner JSG, Kerr T: Impact of a Medically Supervised Safer Injecting Facility on Drug Dealing and Other DrugRelated Crime. Substance Abuse Treatment, Prevention and Policy 2006, $1: 1-4$.

31. Wood E, Tyndall MW, Li K, Lloyd-Smith E, Small W, Montaner JSG, Kerr T: Do Supervised Injecting Facilities Attract Higher-Risk Injection Drug Users? American Journal of Preventive Medicine 2005, 29:126-130.

32. Wood E, Tyndall MW, Montaner JS, Kerr T: Summary of findings from the evaluation of a pilot medically supervised injecting facility. Canadian Medical Association Journal 2006, 175:1399-1404

33. Wood E, Tyndall MW, Qui Z, Zhang R, Montaner JS, Kerr T: Service Uptake and Characteristics of Injection Drug Users Utilizing North America's First Medically Supervised Safer Injection Facility. American Journal of Public Health 2006, 96:770-773.

34. Wood E, Tyndall MW, Stoltz J, Small W, Lloyd-Smith E, Zhang R, Montaner JSG, Kerr T: Factors Associated with Syringe Sharing Among Users of a Medically Supervised Injecting Facility. American Journal of Infectious Diseases 2005, 1:50-54.

35. Wood E, Tyndall MW, Stoltz J, Small W, Zhang R, O'Connell J, Montaner JSG Kerr T: Safer Injecting Education for HIV Prevention Within a Medically Supervised Safer Injecting Facility. International Journal of Drug Policy 2005, 16:281-284.

36. Wood E, Tyndall MW, Zhang R, Stoltz J, Lai C, Montaner JSG, Kerr T: Attendance at Supervised Injecting Facilities and Use of Detoxification Services. New England Journal of Medicine 2006, 354:2512-2514.

37. Wood E, Tyndall MW, Zhang R, Montaner JS, Kerr T: Rate of detoxification service use and its impact among a cohort of supervised injection facility users. Addiction 2007, 102:916-919.

38. Wood RA, Wood E, Lai C, Tyndall MW, Montaner JSG, Kerr T: Nursedelivered safer injection education among a cohort of injection drug users: Evidence from the evaluation of Vancouver's supervised injection facility. International Journal of Drug Policy 2008, 19:183-188.

39. Hwang SW: Science and ideology. Open Medicine 2007, 1:E99-101.

40. Hall N: Federal government appeals ruling on safe-injection site to nation's top court. Vancouver Sun Vancouver: Canwest Publishing 2010.

doi:10.1186/1477-7517-7-23

Cite this article as: Small: An appeal to humanity: legal victory in favour of North America's only supervised injection facility: Insite. Harm Reduction Journal 2010 7:23. 